\title{
Gestational SARS-CoV-2 infection is associated with placental expression of immune and trophoblast genes
}

Authors: Corina Lesseur ${ }^{1}$, Rebecca H. Jessel², Sophie Ohrn², Yula Ma ${ }^{1}$, Qian $\mathrm{Li}^{1}$, Fumiko Dekio ${ }^{3}$, Rachel

I. Brody ${ }^{3}$, James G. Wetmur ${ }^{4}$, Frederieke A.J. Gigase ${ }^{5}$, Molly Lieber ${ }^{2}$, Whitney Lieb ${ }^{2,6,7}$, Jezelle Lynch², Omara Afzal $^{2}$, Erona Ibroci ${ }^{5}$, Anna-Sophie Rommel ${ }^{5}$, Teresa Janevic ${ }^{2,6,7}$, Joanne Stone ${ }^{2}$, Elizabeth A. Howell $^{6,8}$, Romeo R. Galang ${ }^{9}$, Siobhan M. Dolan ${ }^{2}$, Veerle Bergink ${ }^{2,5,7}$, Lotje D. De Witte ${ }^{5}$, Jia Chen ${ }^{1}$

\section{Affiliations}

1. Department of Environmental Medicine and Public Health, Icahn School of Medicine at Mount Sinai, New York City, NY, USA.

2. Department of Obstetrics, Gynecology and Reproductive Science, Icahn School of Medicine at Mount Sinai, New York City, NY, USA.

3. Department of Pathology, Molecular and Cell Based Medicine, Icahn School of Medicine at Mount Sinai, New York City, NY, USA.

4. Department of Microbiology, Icahn School of Medicine at Mount Sinai, Box 1054, 1 Gustave Levy Place, New York, NY, USA.

5. Department of Psychiatry, Icahn School of Medicine at Mount Sinai, New York City, NY, USA.

6. Department of Population Health Science and Policy, Icahn School of Medicine at Mount Sinai, New York City, NY, USA

7. Blavatnik Family Women's Health Research Institute, Icahn School of Medicine at Mount Sinai, New York City, NY, USA.

8. Department of Obstetrics and Gynecology, Perelman School of Medicine, University of Pennsylvania, Philadelphia, PA, USA.

9. CDC COVID-19 Response, Centers for Disease Control and Prevention, Atlanta, GA, USA

Corresponding Author: Jia Chen, ScD. Department of Environmental Medicine and Public Heath, Icahn School of Medicine at Mount Sinai, 1 Gustave L. Levy Place, Box 1057, New York, NY 10029, USA. Tel: +1-212-241-7592; E-mail: jia.chen@mssm.edu. 


\begin{abstract}
Introduction: Maternal SARS-CoV-2 infection during pregnancy is associated with adverse pregnancy outcomes and can have effects on the placenta, even in the absence of severe disease or vertical transmission to the fetus. This study aimed to evaluate histopathologic and molecular effects in the placenta after SARS-CoV-2 infection during pregnancy.

Methods: We performed a study of 45 pregnant participants from the Generation $\mathrm{C}$ prospective cohort study at the Mount Sinai Health System in New York City. We compared histologic features and the expression of 48 immune and trophoblast genes in placentas delivered from 15 SARS-CoV-2 IgG antibody positive and $30 \mathrm{IgG}$ SARS-CoV-2 antibody negative mothers. Statistical analyses were performed using Fisher's exact tests, Spearman correlations and linear regression models.
\end{abstract}

Results: The median gestational age at the time of SARS-CoV-2 IgG serology test was 35 weeks. Two of the IgG positive participants also had a positive RT-PCR nasal swab at delivery. $82.2 \%$ of the infants were delivered at term ( $\geq 37$ weeks), and gestational age at delivery did not differ between the SARSCoV-2 antibody positive and negative groups. No significant differences were detected between the groups in placental histopathology features. Differential expression analyses revealed decreased expression of two trophoblast genes (PSG3 and CGB3) and increased expression of three immune genes (CXCL10, TLR3 and DDX58) in placentas delivered from SARS-CoV-2 IgG positive participants.

Discussion: SARS-CoV-2 infection during pregnancy is associated with gene expression changes of immune and trophoblast genes in the placenta at birth which could potentially contribute to long-term health effects in the offspring.

Keywords: SARS-CoV-2, placenta, gene expression, NanoString. 
medRxiv preprint doi: https://doi.org/10.1101/2022.02.22.22271359; this version posted February 24, 2022. The copyright holder for this preprint (which was not certified by peer review) is the author/funder, who has granted medRxiv a license to display the preprint in perpetuity. All rights reserved. No reuse allowed without permission.

\section{Introduction}

The current pandemic of coronavirus disease 2019 (Covid-19) is caused by infection with the novel severe acute respiratory syndrome coronavirus 2 (SARS-CoV-2). As of January 24, 2022 approximately 352 million infections and 5.6 million deaths have been reported worldwide [1]. The clinical manifestations of SARS-CoV-2 infection vary widely by age group and presence of comorbid conditions, ranging from asymptomatic infection to respiratory failure, multisystem organ failure, and death in critically ill patients [2,3]. Although comprehensive knowledge of the factors involved in severe Covid19 is still needed, dysregulation of the host inflammatory and immune responses $[4,5]$ and thrombosis $[6]$ have been implicated in Covid-19 induced tissue damage.

During pregnancy, the maternal immune system undergoes a series of dynamic changes aimed to promote tolerance of the fetus, that can also influence responses to pathogens, including viruses [7]. Recent reports show that pregnant individuals with severe SARS-CoV-2 infection are at higher risk of intensive care unit admission, mechanical ventilation, extracorporeal membrane oxygenation, and mortality compared to non-pregnant individuals [8,9]. Other studies show that active SARS-CoV-2 infection at delivery (mainly confirmed through a PCR positive test) is associated with obstetric and neonatal complications including increased risk of preterm birth, stillbirth, miscarriage, preeclampsia, emergency cesarean section and higher neonatal morbidity [8, 10-18]. However, in other reports, including ours from New York City and a Denmark study, SARS-CoV-2 IgG seropositivity without RT-PCR positivity at delivery was not associated with adverse pregnancy outcomes $[19,20]$.

The main cell entry pathway of the SARS-CoV-2 virus is dependent on the ACE2 receptor and aided by the TMPRSS2 proteases of the host cells [21]. Early in pregnancy, ACE2 and TMPRSS2 are expressed in placental cytotrophoblast and syncytiotrophoblast cells; however, the expression of these proteins is low in term placentas [22-24]. Recent data suggest that multiple placental cell types are susceptible to infection in explants and immortalized cells after exposure to SARS-CoV-2, and infection susceptibility is related to the levels of $A C E 2$ expression [25-27]. Yet, existing data show that vertical transmission of SARS-CoV-2 is rare; only a few reports have documented presence of the virus in the fetal compartments of the placenta or in newborns [28-30]. Moreover, most of the histopathology studies suggest that placental infection with SARS-CoV-2 is also rare [31-33] and can exist in the absence of vertical transmission $[34,35]$. Additionally, the criteria to diagnose SARS-CoV-2 placental infection have been inconsistent across studies [34, 36-40]. Nonspecific placental histopathologic lesions have also been associated with maternal SARS-CoV-2 infection; a recent meta-analysis reports increases in risk of fetal 
vascular malperfusion, acute and chronic proinflammatory lesions, increased perivillous fibrin, and intervillous thrombosis [41]. These lesions could result from localized placental SARS-CoV-2 infection and/or inflammatory responses to the systemic maternal infection. However, most of the available reports evaluated placental effects of acute SARS-CoV-2 infections mainly from mothers infected at delivery (positive nasopharyngeal PCR test). To date, only few studies have reported changes in expression of immune and inflammatory genes in the placenta, also in cases of acute SARS-CoV-2 infection [42-44]. Understanding the impact of maternal SARS CoV-2 infection on the placenta during pregnancy, including among participants without active infection at delivery, is vital because these placental changes can lead to adverse pregnancy outcomes and long-term effects on the health of newborns [45]. The aim of this work was to evaluate histopathologic and gene expression changes in placentas delivered from SARSCoV-2 IgG positive compared to those from SARS-CoV-2 IgG negative pregnant individuals.

\section{Methods}

\subsection{Study Population}

The Generation $\mathrm{C}$ study is a prospective pregnancy cohort study that aims to examine the impact of SARS-CoV-2 infection during pregnancy on obstetric and neonatal outcomes. Pregnant individuals were recruited at Mount Sinai Hospital (MSH) and Mount Sinai West (MSW) in New York City (NYC) starting April 20, 2020, and recruitment is ongoing [19]. The first COVID-19 case in NYC was officially confirmed on March 1, 2020. Maternal blood samples are collected at multiple time points as part of routine clinical care. Electronic medical record (EMR) review and serological SARS-CoV-2 IgG tests are used to confirm past SARS-CoV-2 infection. Serological testing for IgG antibodies against the SARSCoV-2 spike (S) protein (anti-S IgG) was performed using an enzyme-linked immunosorbent assay (ELISA) developed at the Icahn School of Medicine at Mount Sinai [46]. Placental samples are collected after delivery by the Mount Sinai Biorepository and Pathology Core. All participants provided written informed consent per the institutional review board (IRB)-approved study protocol (IRB at the Icahn School of Medicine at Mount Sinai, protocol IRB-20-03352, April 15, 2020).

For this analysis, we examined a subset of Generation $\mathrm{C}$ participants with and without evidence of past SARS-CoV-2 infection with available placenta tissue blocks collected for medical pathology examination and consent to donate placental tissue; 15 participants were SARS-CoV-2 IgG positive and 30 were SARS-CoV-2 IgG negative. EMR review was conducted to obtain clinical and sociodemographic characteristics of mothers and infants. Participants in this analysis gave birth between May and September of 2020. Since widespread community transmission of SARS-CoV-2 in NYC began in March 2020, we theorized that IgG positive participants who gave birth before or in late September were infected at some 
point during pregnancy. Additionally, all 45 pregnant participants delivered before the first COVID-19 vaccine received Emergency Use Authorization by the U.S. FDA in December 2020.

\subsection{Placenta Histopathology}

After fixation, placentas were processed according to standard protocols including comprehensive gross tissue and histopathologic examination of the umbilical cord, chorionic membranes, and placental villi. Histopathologic review was performed according to the Amsterdam Placental Workshop Group Consensus Statement guidelines [47]. All placentas in the study were reviewed for medical pathology and findings were recorded in the pathology report and in the EMR.

\subsection{Targeted placental gene expression profiling}

RNA was extracted from formaldehyde-fixed paraffin embedded (FFPE) tissue blocks using the Maxwell@ 16 LEV RNA FFPE Purification Kit (Promega, Madison, WI). RNA concentration was determined using the Nanodrop (Thermo Fisher Scientific, MA). Gene expression was profiled with a custom designed NanoString codeset (NanoString, Seattle, WA) panel with 50 probes including genes involved in the inflammatory and/or immune response $(n=25)$, stress response $(n=8)$, cell-type markers $(\mathrm{n}=7)$, SARS-CoV-2 host response ( $\mathrm{n}=6)$, viral SARS-CoV-2 genes (nucleocapsid and envelope proteins) and two housekeeping genes (RPL19, RPLPO) (Supplementary Table 1). RNA (100 nanograms) was hybridized overnight to reporter and capture probes at $65^{\circ} \mathrm{C}$. Next, unbound probes were removed, and purified complexes were aligned and immobilized on four NanoString cartridges using the nCounter Prep station. Cartridges were scanned for gene counts detection in the nCounter Digital Analyzer. All laboratory protocols we performed following manufacturer's instructions. Raw gene expression counts were imported from RCC files using the NanoStringNorm R package (1.2.1.1) [48]. To normalize CodeCount technical variation we used the geometric mean. Background expression levels were calculated based on the mean +/- 2SD of negative control probes. Values below the background limit of detection (LOD) for each sample (mean $+/$ - 2SD of negative control probes) were replaced with LOD/ $\sqrt{ } 2$. We used the geometric mean of the housekeeping genes to normalize for sample RNA sample content. After normalization, counts were $\log 2$ transformed for statistical analyses. Samples with less than $50 \%$ of probes above background were excluded ( $\mathrm{n}=1$, SARS-CoV-2 IgG negative), and probes with counts below the background level in more than $50 \%$ of the samples in each study group were removed $(n=9)$. We used the placental-cell gene markers in the panel to calculate cell-type scores as the average of the $\log 2$ normalized expression of each of the cell type gene marker (PEG10 and PEG3 for cytotrophoblasts, $C G B 3$ and $P S G 3$ for syncytiotrophoblasts, $C D 68$ and $C D 163$ for macrophages and PECAM1 for endothelial cells). 


\subsection{Statistical analyses}

We used summary statistics including median, range, or frequency tables to evaluate the distribution of continuous and categorical variables. We performed bivariate analyses using Fisher exact tests and Wilcoxon signed-rank or Kruskal-Wallis tests as appropriate to evaluate differences in clinical, sociodemographic, and histopathology variables between the SARS-CoV-2 IgG positive versus negative groups. We used principal components analyses to evaluate possible effects of technical (e.g., NanoString cartridge) or biological (e.g., infant sex) covariates in placental gene expression. Differential gene expression analysis by SARS-CoV-2 IgG status was performed using the Limma R package [49] that uses an empirical Bayes method to fit linear models with moderated standard errors for each gene (continuous outcome variable) and the study group (IgG positive versus negative) as the predictor variable. We considered as possible confounders covariates that could influence placenta gene expression including infant sex, gestational age at birth, maternal age, and gestational age at SARS-CoV-2 IgG antibody test. We fitted linear models adjusted for covariates and cell-type proxy scores. Sensitivity analyses were performed excluding two participants with acute infections at delivery to evaluate the impact of SARSCoV-2 PCR positivity at delivery. Statistical significance was set at $p \leq 0.05$. Analyses were performed in $\mathrm{R}$ statistical computing software version 4.1.0 [50].

\section{Results}

\subsection{Demographic, clinical and placenta histopathologic characteristics}

Table 1 displays the characteristics of the Generation C participants included in these analyses $(n=45)$ stratified by study groups: SARS-CoV-2 IgG negative $(n=30)$ and SARS-CoV-2 IgG positive $(n=15)$. The median gestational age of IgG serology testing was 35 weeks with an interquartile range (IQR) between 17.4 and 40.9 weeks. Two of the IgG positive participants were also SARS-CoV-2 PCR positive (nasopharyngeal swab) at the time of the labor and delivery admission. Like in the larger Generation C cohort [19], IgG seropositive participants had higher pre-pregnancy BMI $(p=0.05)$ and were more often Hispanic, or non-Hispanic Black compared to IgG seronegative participants. In contrast, we did not observe differences in other maternal characteristics including age, parity, tobacco use, medical conditions, or obstetric conditions.

The characteristics of the newborns are shown in Table 2. All were live births, $82.2 \%(n=37)$ delivered at term, and 17.8 delivered preterm. We did not detect differences in gestational age between study groups; median gestational age at delivery was 38.9 and 39 weeks for newborns born to IgG-negative and IgGpositive participants, respectively ( $p=0.87$ ). The distribution of newborn sex was slightly different; $66.7 \%$ of newborns in the seropositive group were female and $33.3 \%$ were male, while in the seronegative group 
$33.3 \%$ were female and $66.7 \%$ were male $(p=0.06)$. No differences were noted in birthweight, delivery mode, intrauterine growth restriction, APGAR scores, or NICU admission rates.

The pathology examination showed that placental weight was comparable between IgG seropositive and seronegative participants. Similarly, study groups were not different in other histopathology findings including chronic villitis, deciduitis, acute chorioamnionitis, intervillitis, intervillous thrombosis, fetal vascular thrombosis, decidual arteriopathy, fibrin presence, or chorangiosis (Table 3).

\subsection{Placenta gene expression analysis}

After preprocessing, quality control, the gene expression dataset consisted of 44 samples (IgG negative $\mathrm{n}=29$; IgG positive $\mathrm{n}=15$ ) and 48 genes. Nine genes were consistently below the background level in both study groups and were excluded from differential expression analyses. These included the nucleocapsid and the envelope viral SARS-CoV-2 genes, SARS-CoV-2 cell-entry genes (TMPRSS2, ACE2), and genes involved in the immune and stress response (IL17A, IL23A, IFNL3, IFNA1 and OPRMI). Summary statistics for the expression of the 39 detected genes are shown in Supplementary Table 2. We used principal components analyses to identify effects of biologic and technical covariates in the overall placental gene expression patterns, which did not reveal obvious clustering by SARS-CoV-2 IgG serology or nasal swab PCR status at delivery (Supplementary Fig. 1).

Next, we performed differential expression analyses by SARS-CoV-2 IgG status adjusted for covariates and cell-type proxies (Figure 1). In the analyses adjusted for covariates only, three genes were significantly associated with SARS-CoV-2 IgG antibody status (Figure 1A, Supplementary Table 3). The trophoblast cell-markers PSG3 and CGB3 were downregulated $(\log 2$ fold-change $[\log 2 \mathrm{FC}]=-0.9$, $p=0.002$ and $\log 2 \mathrm{FC}=-0.99, p=0.05$, respectively). $P S G 3$ and $C G B 3$ placental expression levels were highly correlated $\left(\mathrm{rho}=0.6, p=6.1 \times 10^{-5}\right)$. The chemokine $C X C L 10$ was over-expressed $(\log 2 \mathrm{FC}=1.08$, $p=0.02)$ in the $\mathrm{IgG}$ positive group compared to the $\mathrm{IgG}$ negative group. Since placental tissues are heterogenous mixtures of cells, we repeated the differential expression analyses adjusting for covariates and expression cell-type proxies including the average expression PSG3 and CGB3 as syncytiotrophoblast markers. In this analysis, SARS-CoV-2 IgG positivity was associated with increased expression of three genes CXCL10, TLR3 and DDX58 (Figure 1B, Supplementary Table 4). The differences in placental gene expression between the SARS-CoV-2 IgG positive and negative groups ranged between $\log 2 \mathrm{FC}$ of 1.19 for $C X C L 10$ and 0.30 for DDX58 (Figure 2). Sensitivity analyses excluding samples from the two participants who were SARS-CoV-2 IgG positive and PCR positive at delivery showed similar results (Supplemental Fig. 2). 


\section{Discussion}

The effects of SARS-CoV-2 infection on the placenta are not yet well-characterized, particularly in cases of infection during pregnancy without active infection at delivery (i.e., SARS-CoV-2 IgG positive and negative PCR at the delivery admission). In this report, we investigated histopathology and molecular gene expression changes in placentas from 15 mother-infant pairs exposed to SARS-CoV-2 during pregnancy and 30 unexposed controls, part of the Generation C study in NYC. We report differences in the expression of trophoblast specific and immune genes in placentas between IgG positive and negative mothers.

All the placentas in this study underwent medical pathology review, and we found a range of histopathologic findings. However, none of the findings differed significantly with respect to SARS-CoV2 IgG serology status, which is consistent with some studies on Covid-19 and placenta pathology [39, 51]. A recent systematic review and pooled analysis of case-control reports found increased risk of fetal vascular malperfusion, chronic inflammatory pathology, perivillous fibrin, and intervillous thrombosis [41], yet most of the reviewed cases in that analyses were RT-PCR positive at delivery. Our results are inconsistent with these findings, possibly due to limited sample size or because our study population consisted mostly of individuals who were infected with the virus during pregnancy without active infection at delivery.

We detected significant associations between plasma SARS-CoV-2 IgG positivity and lower placental expression of the PSG3 and CGB3. These placenta-specific genes locate to $19 \mathrm{q} 13$ and are highly expressed by trophoblast cells. PSG3 is part of the family of human pregnancy-specific glycoproteins (PSG) that are released to the maternal circulation during pregnancy and are reported to have immunoregulatory and angiogenic functions [52]. CGB3 encodes the beta 3 subunit of the chorionic gonadotropin (hCG), a glycoprotein hormone essential for pregnancy maintenance, that has also been involved in angiogenesis and maternal immunotolerance [53, 54]. Some studies have reported associations between adverse pregnancy outcomes like preeclampsia and circulating levels of PSGs and hCG $[52,53,55,56]$. Importantly, PSG3 and CGB3 are involved in trophoblast syncytialization; alterations in expression of these genes have been described in other viral infections $[57,58]$. However, to our knowledge, there are no studies linking past maternal SARS-CoV-2 infection to altered placental $P S G 3$ or $C G B 3$ expression or trophoblast differentiation.

We also observed increased expression of $C X C L 10$ in placentas delivered from participants exposed to SARS-CoV-2 infection during pregnancy. CXCL10 (C-X-C motif chemokine ligand 10) is a proinflammatory chemokine secreted in response to interferon gamma (IFN $\gamma$ ) involved in the stimulation of 
monocytes, natural killer, and T-cells. Previous investigations have also reported CXCL10 gene expression upregulation in bronchoalveolar lavages [57], nasopharyngeal swabs [58] and male placentas exposed to maternal SARS-CoV-2 infection [43]. Importantly, CXCL10 may also be a key regulator of the "cytokine storm" in response to SARS-CoV-2 infection and circulating levels of CXCL10 are reported to be positively associated with disease severity [59-61]. Two other immune genes, TLR3 and $D D X 58$, were overexpressed in placentas delivered from SARS-CoV-2 IgG positive participants. TLR3 is a member of the toll-like receptor (TLR) family and DDX58 encodes a protein containing RNA helicaseDEAD box motifs (also known as RIG-I). These genes are involved in recognizing double-stranded RNA (dsRNA) released during viral replication and activation of the innate immune response [62, 63]. To date, placental expression of these genes has not been linked to SARS-CoV-2 infection. However, peripheral blood TLR3 gene expression is reduced in patients with severe COVID-19 compared to those with mild forms of the disease [64] and DDX58 expression in human lung cells has been implicated in the initial response against SARS-CoV-2 infection $[65,66]$.

Strengths of the Generation C study include a demographically diverse population of pregnant participants recruited in NYC after the start of the SARS-CoV-2 pandemic. To assess SARS-CoV-2 IgG levels, we used a highly sensitive (95\%) and specific (100\%) serological assay. Also, we explored the effects of SARS-CoV-2 IgG seropositivity on placental histopathology and gene expression simultaneously. We acknowledge that our study is not without limitations. The sample size is limited, and the number of placentas delivered from SARS-CoV-2 IgG positive participants is small. We do not have information on the precise timing of SARS-CoV-2 infection, disease severity, or newborn SARS-CoV-2 IgG levels. Given the exploratory nature of this study, we only measured expression of a small number of genes, and we did not account for multiple testing. Larger studies are needed to investigate the effects of SARS-CoV-2 infection on the whole placental transcriptome. In summary, we found evidence of an association between SARS-CoV-2 infection during pregnancy and placental expression of trophoblast and immune related genes which could potentially contribute to long-term health effects in the offspring. Future research should confirm the observed associations and assess potential long-term implications.

\section{Funding}

The Generation C cohort was established through funding from the US Centers for Disease Control and Prevention (CDC), who also provided technical assistance related to analysis and interpretation of data and writing the report (contract 75D30120C08186). CL is funded through NIH-NICHD R00HD097286. The findings and conclusions in this report are those of the authors and do not necessarily represent the position of the funding agencies. The findings and 
medRxiv preprint doi: https://doi.org/10.1101/2022.02.22.22271359; this version posted February 24, 2022. The copyright holder for this preprint (which was not certified by peer review) is the author/funder, who has granted medRxiv a license to display the preprint in perpetuity.

All rights reserved. No reuse allowed without permission.

conclusions in this report are those of the authors and do not necessarily represent the official position of the CDC.

\section{Declaration of competing interest}

None.

\section{Acknowledgements}

We would like to thank all participants of the Generation C study for their cooperation and contribution to the research field. We would like to thank the members of the Krammer Serology Core Study group and the Mount Sinai Biorepository and Pathology Core, and especially Maryann Huie, Frances Avila, Ariane Benedetto, Anastasiya Dzhun.

\section{REFERENCES}

[1] E. Dong, H. Du, L. Gardner, An interactive web-based dashboard to track COVID-19 in real time, Lancet Infect Dis (2020).

[2] Z. Wu, J.M. McGoogan, Characteristics of and Important Lessons From the Coronavirus Disease 2019 (COVID-19) Outbreak in China: Summary of a Report of 72314 Cases From the Chinese Center for Disease Control and Prevention, JAMA 323(13) (2020) 1239-1242.

[3] A. Krishnan, J.P. Hamilton, S.A. Alqahtani, A.W. T, A narrative review of coronavirus disease 2019 (COVID-19): clinical, epidemiological characteristics, and systemic manifestations, Intern Emerg Med 16(4) (2021) 815-830.

[4] M. Merad, J.C. Martin, Pathological inflammation in patients with COVID-19: a key role for monocytes and macrophages, Nat Rev Immunol (2020) 1-8.

[5] J.L. Schultze, A.C. Aschenbrenner, COVID-19 and the human innate immune system, Cell 184(7) (2021) 1671-1692.

[6] T.C. Hanff, A.M. Mohareb, J. Giri, J.B. Cohen, J.A. Chirinos, Thrombosis in COVID-19, Am J Hematol 95(12) (2020) 1578-1589.

[7] G. Mor, P. Aldo, A.B. Alvero, The unique immunological and microbial aspects of pregnancy, Nat Rev Immunol 17(8) (2017) 469-482.

[8] J. Villar, S. Ariff, R.B. Gunier, R. Thiruvengadam, S. Rauch, A. Kholin, P. Roggero, F. Prefumo, M.S. do Vale, J.A. Cardona-Perez, N. Maiz, I. Cetin, V. Savasi, P. Deruelle, S.R. Easter, J. Sichitiu, C.P. Soto Conti, E. Ernawati, M. Mhatre, J.S. Teji, B. Liu, C. Capelli, M. Oberto, L. Salazar, M.G. Gravett, P.I. Cavoretto, V.B. Nachinab, H. Galadanci, D. Oros, A.I. Ayede, L. Sentilhes, B. Bako, M. Savorani, H. Cena, P.K. García-May, S. Etuk, R. Casale, S. Abd-Elsalam, S. Ikenoue, M.B. Aminu, C. Vecciarelli, E.A. Duro, M.A. Usman, Y. John-Akinola, R. Nieto, E. Ferrazi, Z.A. Bhutta, A. Langer, S.H. Kennedy, A.T. Papageorghiou, Maternal and Neonatal Morbidity and Mortality Among Pregnant Women With and Without COVID-19 Infection: The INTERCOVID Multinational Cohort Study, JAMA Pediatr 175(8) (2021) 817-826.

[9] L.D. Zambrano, S. Ellington, P. Strid, R.R. Galang, T. Oduyebo, V.T. Tong, K.R. Woodworth, J.F. Nahabedian III, E. Azziz-Baumgartner, S.M. Gilboa, Update: characteristics of symptomatic women of reproductive age with laboratory-confirmed SARS-CoV-2 infection by pregnancy status-United States, January 22-October 3, 2020, Morbidity and Mortality Weekly Report 69(44) (2020) 1641.

[10] A.T. Papageorghiou, P. Deruelle, R.B. Gunier, S. Rauch, P.K. García-May, M. Mhatre, M.A. Usman, S. Abd-Elsalam, S. Etuk, L.E. Simmons, R. Napolitano, S. Deantoni, B. Liu, F. Prefumo, V. 
Savasi, M.S. do Vale, E. Baafi, G. Zainab, R. Nieto, N. Maiz, M.B. Aminu, J.A. Cardona-Perez, R. Craik, A. Winsey, G. Tavchioska, B. Bako, D. Oros, A. Rego, A.C. Benski, F. Hassan-Hanga, M. Savorani, F. Giuliani, L. Sentilhes, M. Risso, K. Takahashi, C. Vecchiarelli, S. Ikenoue, R. Thiruvengadam, C.P. Soto Conti, E. Ferrazzi, I. Cetin, V.B. Nachinab, E. Ernawati, E.A. Duro, A. Kholin, M.L. Firlit, S.R. Easter, J. Sichitiu, A. Bowale, R. Casale, R.M. Cerbo, P.I. Cavoretto, B. Eskenazi, J.G. Thornton, Z.A. Bhutta, S.H. Kennedy, J. Villar, Preeclampsia and COVID-19: results from the INTERCOVID prospective longitudinal study, Am J Obstet Gynecol 225(3) (2021) 289.e1-289.e17.

[11] I. Gurol-Urganci, J.E. Jardine, F. Carroll, T. Draycott, G. Dunn, A. Fremeaux, T. Harris, J. Hawdon, E. Morris, P. Muller, L. Waite, K. Webster, J. van der Meulen, A. Khalil, Maternal and perinatal outcomes of pregnant women with SARS-CoV-2 infection at the time of birth in England: national cohort study, Am J Obstet Gynecol (2021).

[12] D. Karasek, R.J. Baer, M.R. McLemore, A.J. Bell, B.E. Blebu, J.A. Casey, K. Coleman-Phox, J.M. Costello, J.N. Felder, E. Flowers, The association of COVID-19 infection in pregnancy with preterm birth: A retrospective cohort study in California, The Lancet Regional Health-Americas (2021) 100027. [13] D. Baud, G. Greub, G. Favre, C. Gengler, K. Jaton, E. Dubruc, L. Pomar, Second-Trimester Miscarriage in a Pregnant Woman With SARS-CoV-2 Infection, Jama (2020).

[14] K.G. Sacinti, E. Kalafat, Y.E. Sukur, A. Koc, Increased incidence of first-trimester miscarriage during the COVID-19 pandemic, Ultrasound Obstet Gynecol 57(6) (2021) 1013-1014.

[15] S.N. Kazemi, B. Hajikhani, H. Didar, S.S. Hosseini, S. Haddadi, F. Khalili, M. Mirsaeidi, M.J. Nasiri, COVID-19 and cause of pregnancy loss during the pandemic: A systematic review, PLoS One 16(8) (2021) e0255994.

[16] A. Conde-Agudelo, R. Romero, SARS-CoV-2 infection during pregnancy and risk of preeclampsia: a systematic review and meta-analysis, American Journal of Obstetrics and Gynecology (2021).

[17] C.L. DeSisto, B. Wallace, R.M. Simeone, K. Polen, J.Y. Ko, D. Meaney-Delman, S.R. Ellington, Risk for Stillbirth Among Women With and Without COVID-19 at Delivery Hospitalization - United States, March 2020-September 2021, MMWR Morb Mortal Wkly Rep 70(47) (2021) 1640-1645. [18] S.Q. Wei, M. Bilodeau-Bertrand, S. Liu, N. Auger, The impact of COVID-19 on pregnancy outcomes: a systematic review and meta-analysis, Cmaj 193(16) (2021) E540-e548.

[19] N.M. Molenaar, A.S. Rommel, L. de Witte, S.M. Dolan, W. Lieb, E. Ibroci, S. Ohrn, J. Lynch, C. Capuano, D. Stadlbauer, F. Krammer, L.B. Zapata, R.I. Brody, V.J. Pop, R.H. Jessel, R.S. Sperling, O. Afzal, F. Gigase, R. Missall, T. Janevic, J. Stone, E.A. Howell, V. Bergink, SARS-CoV-2 during pregnancy and associated outcomes: Results from an ongoing prospective cohort, Paediatr Perinat Epidemiol (2021).

[20] P. Egerup, L. Fich Olsen, A.H. Christiansen, D. Westergaard, E.R. Severinsen, K.V.R. Hviid, A.M. Kolte, A.D. Boje, M.M.F. Bertelsen, L. Prætorius, A. Zedeler, J.R. Nielsen, D. Bang, S. Berntsen, J. Ethelberg-Findsen, D.M. Storm, J. Bello-Rodríguez, A. Ingham, J. Ollé-López, E.R. Hoffmann, C. Wilken-Jensen, L. Krebs, F.S. Jørgensen, H. Westh, H.L. Jørgensen, N. la Cour Freiesleben, H.S. Nielsen, Severe Acute Respiratory Syndrome Coronavirus 2 (SARS-CoV-2) Antibodies at Delivery in Women, Partners, and Newborns, Obstet Gynecol 137(1) (2021) 49-55.

[21] M. Letko, A. Marzi, V. Munster, Functional assessment of cell entry and receptor usage for SARSCoV-2 and other lineage B betacoronaviruses, Nat Microbiol 5(4) (2020) 562-569.

[22] R. Pique-Regi, R. Romero, A.L. Tarca, F. Luca, Y. Xu, A. Alazizi, Y. Leng, C.D. Hsu, N. GomezLopez, Does the human placenta express the canonical cell entry mediators for SARS-CoV-2?, Elife 9 (2020).

[23] N. Ashary, A. Bhide, P. Chakraborty, S. Colaco, A. Mishra, K. Chhabria, M.K. Jolly, D. Modi, Single-Cell RNA-seq Identifies Cell Subsets in Human Placenta That Highly Expresses Factors Driving Pathogenesis of SARS-CoV-2, Front Cell Dev Biol 8 (2020) 783.

[24] A. Lu-Culligan, A.R. Chavan, P. Vijayakumar, L. Irshaid, E.M. Courchaine, K.M. Milano, Z. Tang, S.D. Pope, E. Song, C.B.F. Vogels, W.J. Lu-Culligan, K.H. Campbell, A. Casanovas-Massana, S. Bermejo, J.M. Toothaker, H.J. Lee, F. Liu, W. Schulz, J. Fournier, M.C. Muenker, A.J. Moore, L. Konnikova, K.M. Neugebauer, A. Ring, N.D. Grubaugh, A.I. Ko, R. Morotti, S. Guller, H.J. Kliman, A. 
medRxiv preprint doi: https://doi.org/10.1101/2022.02.22.22271359; this version posted February 24, 2022. The copyright holder for this preprint (which was not certified by peer review) is the author/funder, who has granted medRxiv a license to display the preprint in perpetuity.

All rights reserved. No reuse allowed without permission.

Iwasaki, S.F. Farhadian, Maternal respiratory SARS-CoV-2 infection in pregnancy is associated with a robust inflammatory response at the maternal-fetal interface, Med (N Y) 2(5) (2021) 591-610.e10.

[25] A. Fahmi, M. Brügger, T. Démoulins, B. Zumkehr, B.I. Oliveira Esteves, L. Bracher, C. Wotzkow, F. Blank, V. Thiel, D. Baud, M.P. Alves, SARS-CoV-2 can infect and propagate in human placenta explants, Cell Rep Med (2021) 100456.

[26] S. Verma, C.S. Joshi, R.B. Silverstein, M. He, E.B. Carter, I.U. Mysorekar, SARS-CoV-2 colonization of maternal and fetal cells of the human placenta promotes alteration of local reninangiotensin system, Med (N Y) 2(5) (2021) 575-590.e5.

[27] E.S. Taglauer, E.M. Wachman, L. Juttukonda, T. Klouda, J. Kim, Q. Wang, A. Ishiyama, D.J. Hackam, K. Yuan, H. Jia, Acute SARS-CoV-2 infection in pregnancy is associated with placental ACE-2 shedding, bioRxiv (2021) 2021.11.19.469335.

[28] L. Zeng, S. Xia, W. Yuan, K. Yan, F. Xiao, J. Shao, W. Zhou, Neonatal Early-Onset Infection With SARS-CoV-2 in 33 Neonates Born to Mothers With COVID-19 in Wuhan, China, JAMA Pediatrics (2020).

[29] M.C. Alzamora, T. Paredes, D. Caceres, C.M. Webb, L.M. Valdez, M. La Rosa, Severe COVID-19 during Pregnancy and Possible Vertical Transmission, Am J Perinatol 37(8) (2020) 861-865.

[30] L. Dong, J. Tian, S. He, C. Zhu, J. Wang, C. Liu, J. Yang, Possible Vertical Transmission of SARSCoV-2 From an Infected Mother to Her Newborn, Jama 323(18) (2020) 1846-1848.

[31] A.J. Vivanti, C. Vauloup-Fellous, S. Prevot, V. Zupan, C. Suffee, J. Do Cao, A. Benachi, D. De Luca, Transplacental transmission of SARS-CoV-2 infection, Nat Commun 11(1) (2020) 3572.

[32] H. Hosier, S.F. Farhadian, R.A. Morotti, U. Deshmukh, A. Lu-Culligan, K.H. Campbell, Y. Yasumoto, C.B. Vogels, A. Casanovas-Massana, P. Vijayakumar, B. Geng, C.D. Odio, J. Fournier, A.F. Brito, J.R. Fauver, F. Liu, T. Alpert, R. Tal, K. Szigeti-Buck, S. Perincheri, C. Larsen, A.M. Gariepy, G. Aguilar, K.L. Fardelmann, M. Harigopal, H.S. Taylor, C.M. Pettker, A.L. Wyllie, C.D. Cruz, A.M. Ring, N.D. Grubaugh, A.I. Ko, T.L. Horvath, A. Iwasaki, U.M. Reddy, H.S. Lipkind, SARS-CoV-2 infection of the placenta, J Clin Invest 130(9) (2020) 4947-4953.

[33] L. Patanè, D. Morotti, M.R. Giunta, C. Sigismondi, M.G. Piccoli, L. Frigerio, G. Mangili, M. Arosio, G. Cornolti, Vertical transmission of coronavirus disease 2019: severe acute respiratory syndrome coronavirus 2 RNA on the fetal side of the placenta in pregnancies with coronavirus disease 2019-positive mothers and neonates at birth, Am J Obstet Gynecol MFM 2(3) (2020) 100145.

[34] L. Debelenko, I. Katsyv, A.M. Chong, L. Peruyero, M. Szabolcs, A.C. Uhlemann, Trophoblast damage with acute and chronic intervillositis: disruption of the placental barrier by severe acute respiratory syndrome coronavirus 2, Hum Pathol 109 (2021) 69-79.

[35] L. Dong, S. Pei, Q. Ren, S. Fu, L. Yu, H. Chen, X. Chen, M. Yin, Evaluation of vertical transmission of SARS-CoV-2 in utero: Nine pregnant women and their newborns, Placenta 111 (2021) 91-96.

[36] D. Levitan, V. London, R.A. McLaren, J.D. Mann, K. Cheng, M. Silver, K.S. Balhotra, S. McCalla, K. Loukeris, Histologic and Immunohistochemical Evaluation of 65 Placentas From Women With Polymerase Chain Reaction-Proven Severe Acute Respiratory Syndrome Coronavirus 2 (SARS-CoV-2) Infection, Arch Pathol Lab Med 145(6) (2021) 648-656.

[37] L. Resta, A. Vimercati, G. Cazzato, G. Mazzia, E. Cicinelli, A. Colagrande, M. Fanelli, S.V. Scarcella, O. Ceci, R. Rossi, SARS-CoV-2 and Placenta: New Insights and Perspectives, Viruses 13(5) (2021).

[38] L. Bertero, F. Borella, G. Botta, A. Carosso, S. Cosma, M. Bovetti, M. Carosso, G. Abbona, G. Collemi, M. Papotti, P. Cassoni, C. Benedetto, Placenta histopathology in SARS-CoV-2 infection: analysis of a consecutive series and comparison with control cohorts, Virchows Arch (2021) 1-14. [39] J.L. Hecht, B. Quade, V. Deshpande, M. Mino-Kenudson, D.T. Ting, N. Desai, B. Dygulska, T. Heyman, C. Salafia, D. Shen, S.V. Bates, D.J. Roberts, SARS-CoV-2 can infect the placenta and is not associated with specific placental histopathology: a series of 19 placentas from COVID-19-positive mothers, Mod Pathol 33(11) (2020) 2092-2103.

[40] D.J. Roberts, A.G. Edlow, R.J. Romero, C.B. Coyne, D.T. Ting, J.L. Hornick, S.R. Zaki, U. Das Adhikari, L. Serghides, S.L. Gaw, T.D. Metz, A standardized definition of placental infection by SARS- 
medRxiv preprint doi: https://doi.org/10.1101/2022.02.22.22271359; this version posted February 24, 2022. The copyright holder for this preprint (which was not certified by peer review) is the author/funder, who has granted medRxiv a license to display the preprint in perpetuity.

All rights reserved. No reuse allowed without permission.

$\mathrm{CoV}-2$, a consensus statement from the National Institutes of Health/Eunice Kennedy Shriver National Institute of Child Health and Human Development SARS-CoV-2 Placental Infection Workshop, Am J Obstet Gynecol (2021).

[41] R.D. Girolamo, A. Khalil, S. Alameddine, E. D'Angelo, C. Galliani, B. Matarrelli, D. Buca, M. Liberati, G. Rizzo, F. D'Antonio, Placental histopathology after SARS-CoV-2 infection in pregnancy: a systematic review and meta-analysis, Am J Obstet Gynecol MFM (2021) 100468.

[42] C. Fenizia, M. Biasin, I. Cetin, P. Vergani, D. Mileto, A. Spinillo, M.R. Gismondo, F. Perotti, C. Callegari, A. Mancon, S. Cammarata, I. Beretta, M. Nebuloni, D. Trabattoni, M. Clerici, V. Savasi, Analysis of SARS-CoV-2 vertical transmission during pregnancy, Nat Commun 11(1) (2020) 5128. [43] E.A. Bordt, L.L. Shook, C. Atyeo, K.M. Pullen, R.M. De Guzman, M.C. Meinsohn, M. Chauvin, S. Fischinger, L.J. Yockey, K. James, R. Lima, L.M. Yonker, A. Fasano, S. Brigida, L.M. Bebell, D.J. Roberts, D. Pépin, J.R. Huh, S.D. Bilbo, J.Z. Li, A. Kaimal, D.J. Schust, K.J. Gray, D. Lauffenburger, G. Alter, A.G. Edlow, Maternal SARS-CoV-2 infection elicits sexually dimorphic placental immune responses, Sci Transl Med 13(617) (2021) eabi7428.

[44] V. Garcia-Flores, R. Romero, Y. Xu, K.R. Theis, M. Arenas-Hernandez, D. Miller, A. Peyvandipour, G. Bhatti, J. Galaz, M. Gershater, D. Levenson, E. Pusod, L. Tao, D. Kracht, V. Florova, Y. Leng, K. Motomura, R. Para, M. Faucett, C.D. Hsu, G. Zhang, A.L. Tarca, R. Pique-Regi, N. Gomez-Lopez, Maternal-fetal immune responses in pregnant women infected with SARS-CoV-2, Nat Commun 13(1) (2022) 320.

[45] J.A. Goldstein, K. Gallagher, C. Beck, R. Kumar, A.D. Gernand, Maternal-Fetal Inflammation in the Placenta and the Developmental Origins of Health and Disease, Front Immunol 11 (2020) 531543. [46] D. Stadlbauer, F. Amanat, V. Chromikova, K. Jiang, S. Strohmeier, G.A. Arunkumar, J. Tan, D. Bhavsar, C. Capuano, E. Kirkpatrick, P. Meade, R.N. Brito, C. Teo, M. McMahon, V. Simon, F. Krammer, SARS-CoV-2 Seroconversion in Humans: A Detailed Protocol for a Serological Assay, Antigen Production, and Test Setup, Curr Protoc Microbiol 57(1) (2020) e100.

[47] T.Y. Khong, E.E. Mooney, I. Ariel, N.C. Balmus, T.K. Boyd, M.A. Brundler, H. Derricott, M.J. Evans, O.M. Faye-Petersen, J.E. Gillan, A.E. Heazell, D.S. Heller, S.M. Jacques, S. Keating, P. Kelehan, A. Maes, E.M. McKay, T.K. Morgan, P.G. Nikkels, W.T. Parks, R.W. Redline, I. Scheimberg, M.H. Schoots, N.J. Sebire, A. Timmer, G. Turowski, J.P. van der Voorn, I. van Lijnschoten, S.J. Gordijn, Sampling and Definitions of Placental Lesions: Amsterdam Placental Workshop Group Consensus Statement, Arch Pathol Lab Med 140(7) (2016) 698-713.

[48] D. Waggott, K. Chu, S. Yin, B.G. Wouters, F.F. Liu, P.C. Boutros, NanoStringNorm: an extensible R package for the pre-processing of NanoString mRNA and miRNA data, Bioinformatics 28(11) (2012) 1546-8.

[49] M.E. Ritchie, B. Phipson, D. Wu, Y. Hu, C.W. Law, W. Shi, G.K. Smyth, limma powers differential expression analyses for RNA-sequencing and microarray studies, Nucleic Acids Res 43(7) (2015) e47. [50] R.C. Team, R: A language and environment for statistical computing, R Foundation for Statistical Computing, Vienna, Austria, 2021.

[51] J.T. Suhren, A. Meinardus, K. Hussein, N. Schaumann, Meta-analysis on COVID-19-pregnancyrelated placental pathologies shows no specific pattern, Placenta 117 (2021) 72-77.

[52] S. Teglund, A. Olsen, W.N. Khan, L. Frängsmyr, S. Hammarström, The pregnancy-specific glycoprotein (PSG) gene cluster on human chromosome 19: fine structure of the 11 PSG genes and identification of 6 new genes forming a third subgroup within the carcinoembryonic antigen (CEA) family, Genomics 23(3) (1994) 669-84.

[53] T. Fournier, J. Guibourdenche, D. Evain-Brion, Review: hCGs: different sources of production, different glycoforms and functions, Placenta 36 Suppl 1 (2015) S60-5.

[54] A. Schumacher, A.C. Zenclussen, Human Chorionic Gonadotropin-Mediated Immune Responses That Facilitate Embryo Implantation and Placentation, Front Immunol 10 (2019) 2896.

[55] T. Moore, G.S. Dveksler, Pregnancy-specific glycoproteins: complex gene families regulating maternal-fetal interactions, Int J Dev Biol 58(2-4) (2014) 273-80. 
medRxiv preprint doi: https://doi.org/10.1101/2022.02.22.22271359; this version posted February 24, 2022. The copyright holder for this preprint (which was not certified by peer review) is the author/funder, who has granted medRxiv a license to display the preprint in perpetuity.

All rights reserved. No reuse allowed without permission.

[56] W. Zimmermann, R. Kammerer, The immune-modulating pregnancy-specific glycoproteins evolve rapidly and their presence correlates with hemochorial placentation in primates, BMC Genomics 22(1) (2021) 128.

[57] R.A. Grant, L. Morales-Nebreda, N.S. Markov, S. Swaminathan, M. Querrey, E.R. Guzman, D.A. Abbott, H.K. Donnelly, A. Donayre, I.A. Goldberg, Z.M. Klug, N. Borkowski, Z. Lu, H. Kihshen, Y. Politanska, L. Sichizya, M. Kang, A. Shilatifard, C. Qi, J.W. Lomasney, A.C. Argento, J.M. Kruser, E.S. Malsin, C.O. Pickens, S.B. Smith, J.M. Walter, A.E. Pawlowski, D. Schneider, P. Nannapaneni, H. Abdala-Valencia, A. Bharat, C.J. Gottardi, G.R.S. Budinger, A.V. Misharin, B.D. Singer, R.G. Wunderink, Circuits between infected macrophages and T cells in SARS-CoV-2 pneumonia, Nature 590(7847) (2021) 635-641.

[58] D. Butler, C. Mozsary, C. Meydan, J. Foox, J. Rosiene, A. Shaiber, D. Danko, E. Afshinnekoo, M. MacKay, F.J. Sedlazeck, N.A. Ivanov, M. Sierra, D. Pohle, M. Zietz, U. Gisladottir, V. Ramlall, E.T. Sholle, E.J. Schenck, C.D. Westover, C. Hassan, K. Ryon, B. Young, C. Bhattacharya, D.L. Ng, A.C. Granados, Y.A. Santos, V. Servellita, S. Federman, P. Ruggiero, A. Fungtammasan, C.S. Chin, N.M. Pearson, B.W. Langhorst, N.A. Tanner, Y. Kim, J.W. Reeves, T.D. Hether, S.E. Warren, M. Bailey, J. Gawrys, D. Meleshko, D. Xu, M. Couto-Rodriguez, D. Nagy-Szakal, J. Barrows, H. Wells, N.B. O'Hara, J.A. Rosenfeld, Y. Chen, P.A.D. Steel, A.J. Shemesh, J. Xiang, J. Thierry-Mieg, D. Thierry-Mieg, A. Iftner, D. Bezdan, E. Sanchez, T.R. Campion, Jr., J. Sipley, L. Cong, A. Craney, P. Velu, A.M. Melnick, S. Shapira, I. Hajirasouliha, A. Borczuk, T. Iftner, M. Salvatore, M. Loda, L.F. Westblade, M. Cushing, S. Wu, S. Levy, C. Chiu, R.E. Schwartz, N. Tatonetti, H. Rennert, M. Imielinski, C.E. Mason, Shotgun transcriptome, spatial omics, and isothermal profiling of SARS-CoV-2 infection reveals unique host responses, viral diversification, and drug interactions, Nat Commun 12(1) (2021) 1660.

[59] F. Coperchini, L. Chiovato, M. Rotondi, Interleukin-6, CXCL10 and Infiltrating Macrophages in COVID-19-Related Cytokine Storm: Not One for All But All for One!, Front Immunol 12 (2021) 668507. [60] M. Blot, J.B. Bour, J.P. Quenot, A. Bourredjem, M. Nguyen, J. Guy, S. Monier, M. Georges, A. Large, A. Dargent, A. Guilhem, S. Mouries-Martin, J. Barben, B. Bouhemad, P.E. Charles, P. Chavanet, C. Binquet, L. Piroth, The dysregulated innate immune response in severe COVID-19 pneumonia that could drive poorer outcome, J Transl Med 18(1) (2020) 457.

[61] N.I. Lorè, R. De Lorenzo, P.M.V. Rancoita, F. Cugnata, A. Agresti, F. Benedetti, M.E. Bianchi, C. Bonini, A. Capobianco, C. Conte, A. Corti, R. Furlan, P. Mantegani, N. Maugeri, C. Sciorati, F. Saliu, L. Silvestri, C. Tresoldi, F. Ciceri, P. Rovere-Querini, C. Di Serio, D.M. Cirillo, A.A. Manfredi, CXCL10 levels at hospital admission predict COVID-19 outcome: hierarchical assessment of 53 putative inflammatory biomarkers in an observational study, Mol Med 27(1) (2021) 129.

[62] H. Kumar, T. Kawai, S. Akira, Toll-like receptors and innate immunity, Biochem Biophys Res Commun 388(4) (2009) 621-5.

[63] J. Rehwinkel, M.U. Gack, RIG-I-like receptors: their regulation and roles in RNA sensing, Nat Rev Immunol 20(9) (2020) 537-551.

[64] M.C.S. Menezes, A.D.M. Veiga, T. Martins de Lima, S. Kunimi Kubo Ariga, H. Vieira Barbeiro, C. de Lucena Moreira, A.A.S. Pinto, R.A. Brandao, J.F. Marchini, J.C. Alencar, L.O. Marino, L.M. Gomez, N. Olsen Saraiva Camara, H.P. Souza, Lower peripheral blood Toll-like receptor 3 expression is associated with an unfavorable outcome in severe COVID-19 patients, Sci Rep 11(1) (2021) 15223.

[65] T. Yamada, S. Sato, Y. Sotoyama, Y. Orba, H. Sawa, H. Yamauchi, M. Sasaki, A. Takaoka, RIG-I triggers a signaling-abortive anti-SARS-CoV-2 defense in human lung cells, Nat Immunol 22(7) (2021) 820-828.

[66] X. Yin, L. Riva, Y. Pu, L. Martin-Sancho, J. Kanamune, Y. Yamamoto, K. Sakai, S. Gotoh, L. Miorin, P.D. De Jesus, C.C. Yang, K.M. Herbert, S. Yoh, J.F. Hultquist, A. García-Sastre, S.K. Chanda, MDA5 Governs the Innate Immune Response to SARS-CoV-2 in Lung Epithelial Cells, Cell Rep 34(2) (2021) 108628. 
Table 1. Maternal characteristics stratified by SARS-CoV-2 IgG status

\begin{tabular}{|c|c|c|c|c|}
\hline & $\begin{array}{l}\text { Total } \\
n=45\end{array}$ & $\begin{array}{c}\text { SARS-CoV-2 IgG } \\
\text { negative } \\
\text { n=30 }\end{array}$ & $\begin{array}{c}\text { SARS-CoV-2 } \\
\text { IgG positive } \\
\quad n=15\end{array}$ & $p$-value* \\
\hline Maternal age & 34 [27-46] & 35 [28-42] & $33[27-46]$ & 0.21 \\
\hline & $25.4[17.3-$ & & $28.3[21.2-$ & \\
\hline Pre-pregnancy BMI & 59.7] & $24.9[17.3-59.7]$ & 39.6] & 0.05 \\
\hline $\begin{array}{l}\text { Gestational age (wks) at IgG } \\
\text { serology }\end{array}$ & $\begin{array}{l}34.9[17.4- \\
\quad 40.9]\end{array}$ & 35.4 [17.4-40.9] & $34.1[21-36.9]$ & 0.24 \\
\hline \multicolumn{5}{|l|}{ SARS-CoV-2 status at delivery } \\
\hline IgG-negative/PCR-negative & $30(66.7 \%)$ & $30(100 \%)$ & $0(0 \%)$ & \\
\hline IgG-positive/PCR-negative & $13(28.9 \%)$ & $0(0 \%)$ & $13(86.7 \%)$ & \\
\hline IgG-positive/PCR-positive & $2(4.4 \%)$ & $0(0 \%)$ & $2(13.3 \%)$ & \\
\hline Maternal Race/Ethnicity & & & & 0.10 \\
\hline Asian & $5(11.1 \%)$ & $4(13.3 \%)$ & $1(6.7 \%)$ & \\
\hline Black, non-Hispanic & $6(13.3 \%)$ & $2(6.7 \%)$ & $4(26.7 \%)$ & \\
\hline Hispanic & $3(6.7 \%)$ & $1(3.3 \%)$ & $2(13.3 \%)$ & \\
\hline Other & $9(20 \%)$ & $5(16.7 \%)$ & $4(26.7 \%)$ & \\
\hline White, non-Hispanic & $21(46.7 \%)$ & $17(56.7 \%)$ & $4(26.7 \%)$ & \\
\hline Unknown & $1(2.2 \%)$ & $1(3.3 \%)$ & $0(0 \%)$ & \\
\hline Parity & & & & 1 \\
\hline multiparous & $20(44.4 \%)$ & $13(43.3 \%)$ & $7(46.7 \%)$ & \\
\hline nulliparous & $25(55.6 \%)$ & $17(56.7 \%)$ & $8(53.3 \%)$ & \\
\hline Tobacco & & & & 0.28 \\
\hline Never & $41(91.1 \%)$ & $26(86.7 \%)$ & $15(100 \%)$ & \\
\hline Quit & $4(8.9 \%)$ & $4(13.3 \%)$ & $0(0 \%)$ & \\
\hline Gestational diabetes & & & & 1.00 \\
\hline No & $35(77.8 \%)$ & $23(76.7 \%)$ & $12(80 \%)$ & \\
\hline Yes & $10(22.2 \%)$ & $7(23.3 \%)$ & $3(20 \%)$ & \\
\hline Gestational hypertension & & & & 0.65 \\
\hline No & $39(86.7 \%)$ & $25(83.3 \%)$ & $14(93.3 \%)$ & \\
\hline Yes & $6(13.3 \%)$ & $5(16.7 \%)$ & $1(6.7 \%)$ & \\
\hline Chronic hypertension & & & & 0.59 \\
\hline No & $41(91.1 \%)$ & $28(93.3 \%)$ & $13(86.7 \%)$ & \\
\hline Yes & $4(8.9 \%)$ & $2(6.7 \%)$ & $2(13.3 \%)$ & \\
\hline Asthma & & & & 0.70 \\
\hline No & $37(82.2 \%)$ & $24(80 \%)$ & $13(86.7 \%)$ & \\
\hline Yes & $8(17.8 \%)$ & $6(20 \%)$ & $2(13.3 \%)$ & \\
\hline Preeclampsia & & & & 0.28 \\
\hline No & $41(91.1 \%)$ & $26(86.7 \%)$ & $15(100 \%)$ & \\
\hline Yes & $4(8.9 \%)$ & $4(13.3 \%)$ & $0(0 \%)$ & \\
\hline HELLP & & & & 1.00 \\
\hline No & $44(97.8 \%)$ & $29(96.7 \%)$ & $15(100 \%)$ & \\
\hline Yes & $1(2.2 \%)$ & $1(3.3 \%)$ & $0(0 \%)$ & \\
\hline
\end{tabular}

Categorical variables are frequencies and percentages $(\%)$. Continuous variables summarized with median [range]. * Wilcoxon test for continuous variables, fisher test for categorical variables 
Table 2. Newborn characteristics stratified by maternal SARS-CoV-2 IgG status

\begin{tabular}{|c|c|c|c|c|}
\hline & $\begin{array}{c}\text { Total } \\
n=45\end{array}$ & $\begin{array}{c}\text { SARS-CoV-2 IgG } \\
\text { negative } \\
n=30\end{array}$ & $\begin{array}{c}\text { SARS-CoV-2 } \\
\text { IgG positive } \\
\text { n }=15\end{array}$ & $p$-value* \\
\hline Birth weight (Kg) & 3.38 [2.2-3.93] & $3.23[2.32-3.93]$ & 3.44 [2.19-3.79] & 0.90 \\
\hline Gestational age (wks) at birth & $38.9[34-41.6]$ & 38.9 [35.4-40.9] & 39 [34-41.6] & 0.87 \\
\hline APGAR at 1 minute & 9 [4-9] & 8 [4-9] & 9 [7-9] & 0.31 \\
\hline APGAR at 5 minute & 9 [8-9] & 9 [8-9] & 9 [9-9] & 0.14 \\
\hline Infant sex & & & & 0.06 \\
\hline Female & $20(44.4 \%)$ & $10(33.3 \%)$ & $10(66.7 \%)$ & \\
\hline Male & $25(55.6 \%)$ & $20(66.7 \%)$ & $5(33.3 \%)$ & \\
\hline Birth weight group & & & & 0.49 \\
\hline AGA & $37(82.2 \%)$ & $23(76.7 \%)$ & $14(93.3 \%)$ & \\
\hline LGA & $4(8.9 \%)$ & $3(10 \%)$ & $1(6.7 \%)$ & \\
\hline SGA & $4(8.9 \%)$ & $4(13.3 \%)$ & $0(0 \%)$ & \\
\hline Delivery mode & & & & 0.75 \\
\hline C-Section & $18(40 \%)$ & $13(43.3 \%)$ & $5(33.3 \%)$ & \\
\hline Vaginal & $27(60 \%)$ & $17(56.7 \%)$ & $10(66.7 \%)$ & \\
\hline IUGR & & & & 0.54 \\
\hline No & $42(93.3 \%)$ & $27(90 \%)$ & $15(100 \%)$ & \\
\hline Yes & $3(6.7 \%)$ & $3(10 \%)$ & $0(0 \%)$ & \\
\hline Preterm birth & & & & 1 \\
\hline No & $37(82.2 \%)$ & $25(83.3 \%)$ & $12(80 \%)$ & \\
\hline Yes & $8(17.8 \%)$ & $5(16.7 \%)$ & $3(20 \%)$ & \\
\hline NICU admission & & & & 0.70 \\
\hline No & $36(80 \%)$ & $23(76.7 \%)$ & $13(86.7 \%)$ & \\
\hline Yes & $9(20 \%)$ & $7(23.3 \%)$ & $2(13.3 \%)$ & \\
\hline
\end{tabular}

Continuous variables summarized with median [range].

Categorical variables are frequencies and percentages $(\%)$.

* Wilcoxon test for continuous variables, Fisher's test for categorical variables 
Table 3. Histopathology characteristics stratified by maternal SARS-CoV-2 IgG status

\begin{tabular}{|lcccc|}
\hline & $\begin{array}{c}\text { Total } \\
\mathbf{n}=\mathbf{4 5}\end{array}$ & $\begin{array}{c}\text { SARS-CoV-2 IgG } \\
\text { negative } \\
\mathbf{n}=\mathbf{3 0}\end{array}$ & $\begin{array}{c}\text { SARS-CoV-2 } \\
\text { IgG positive } \\
\mathbf{n = 1 5}\end{array}$ & p-value* \\
Placental weight $(\mathrm{g})$ & $501[304-644]$ & $476[304-644]$ & $504[317-568]$ & 0.92 \\
Chronic villitis & $2(4.4 \%)$ & $1(3.3 \%)$ & $1(6.7 \%)$ & 1 \\
Deciduitis & $2(4.4 \%)$ & $2(6.7 \%)$ & $0(0 \%)$ & 0.55 \\
Acute chorioamnionitis & $10(22.2 \%)$ & $6(20 \%)$ & $4(26.7 \%)$ & 0.71 \\
Intervillitis & $1(2.2 \%)$ & $0(0 \%)$ & $1(6.7 \%)$ & 0.33 \\
Intervillous thrombosis & $2(4.4 \%)$ & $2(6.7 \%)$ & $0(0 \%)$ & 0.55 \\
Fetal vascular thrombosis & $1(2.2 \%)$ & $1(3.3 \%)$ & $0(0 \%)$ & 1.00 \\
Decidual arteriopathy & $5(11.1 \%)$ & $5(16.7 \%)$ & $0(0 \%)$ & 0.15 \\
Fibrin & $32(71.1 \%)$ & $22(73.3 \%)$ & $10(66.7 \%)$ & 0.73 \\
Chorangiosis & $2(4.4 \%)$ & $2(6.7 \%)$ & $0(0 \%)$ & 0.55 \\
Any inflammatory lesion ${ }^{\#}$ & $14(31.3 \%)$ & $7(23.3 \%)$ & $7(46.7 \%)$ & 0.17 \\
\hline
\end{tabular}

Continuous variables summarized with median [range]. Categorical variables are frequencies and percentages (\%).

* Wilcoxon test for continuous variables, Fisher's exact test for categorical variables.

\# Combined variable including acute chorioamnionitis, chronic villitis, intervillitis and deciduitis. 
medRxiv preprint doi: https://doi.org/10.1101/2022.02.22.22271359; this version posted February 24, 2022. The copyright holder for this preprint (which was not certified by peer review) is the author/funder, who has granted medRxiv a license to display the preprint in perpetuity. All rights reserved. No reuse allowed without permission.

Figure 1. Volcano plots of differential gene expression analyses in placentas from SARS-CoV-2 IgG positive $(\mathrm{n}=15)$ versus IgG negative $(\mathrm{n}=29)$ participants. A. Linear models adjusted for infant sex, birthweight, gestational age at birth and maternal age. B. Linear models adjusted for infant sex, birthweight, gestational age at birth and maternal age and cell-type gene expression proxies. The $\mathrm{x}$-axis is the $\log 2$ fold change (FC) and $y$-axis is the $-\log 10 P$-value, the highlighted in blue are genes with $p<0.05$. The horizontal dashed line corresponds to $p=0.05$.

A

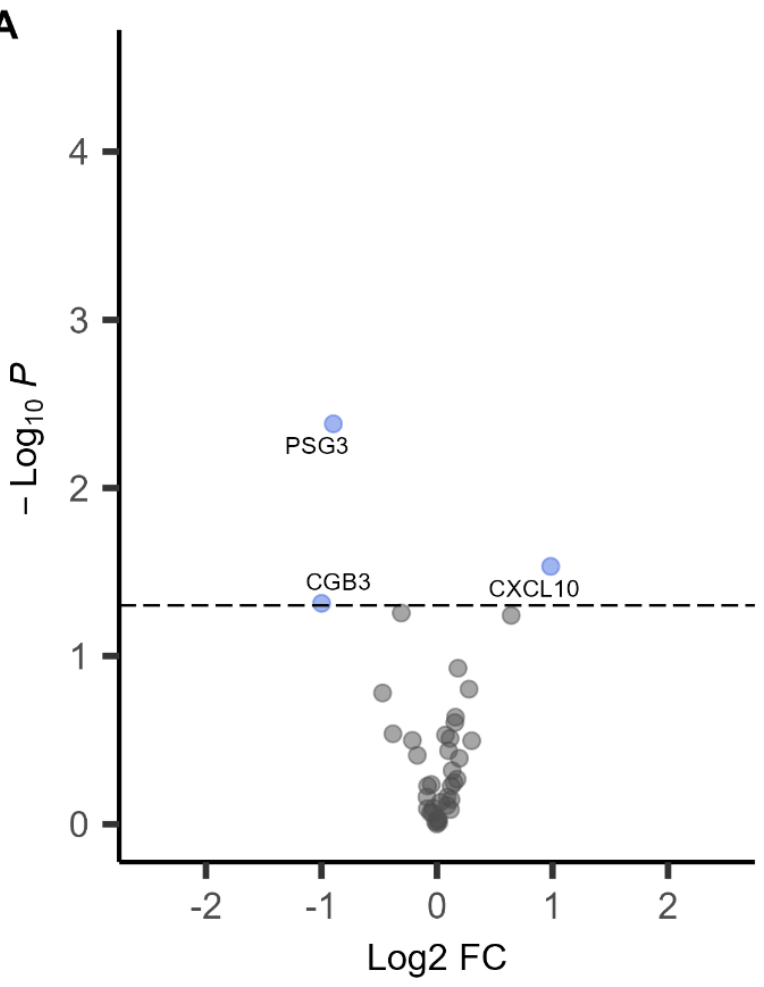

B

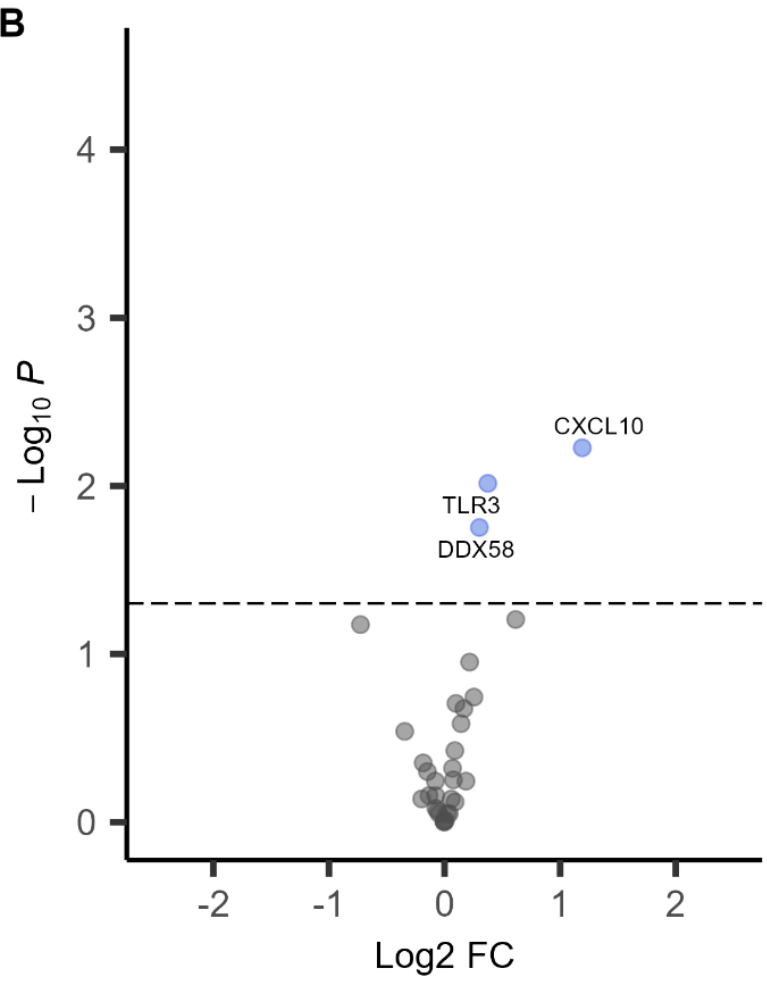


medRxiv preprint doi: https://doi.org/10.1101/2022.02.22.22271359; this version posted February 24, 2022. The copyright holder for this preprint (which was not certified by peer review) is the author/funder, who has granted medRxiv a license to display the preprint in perpetuity. All rights reserved. No reuse allowed without permission.

Figure 2. Box plots of gene expression in placentas delivered by SARS-CoV-2 IgG positive versus IgG negative participants. Top panel. PSG3 and CGB3 trophoblast genes. Bottom panel CXCL10, TLR3 and DDX58 immune genes. The y-axis is the log2 fold change (FC) and x-axis is SARS-CoV-2 IgG antibody group.
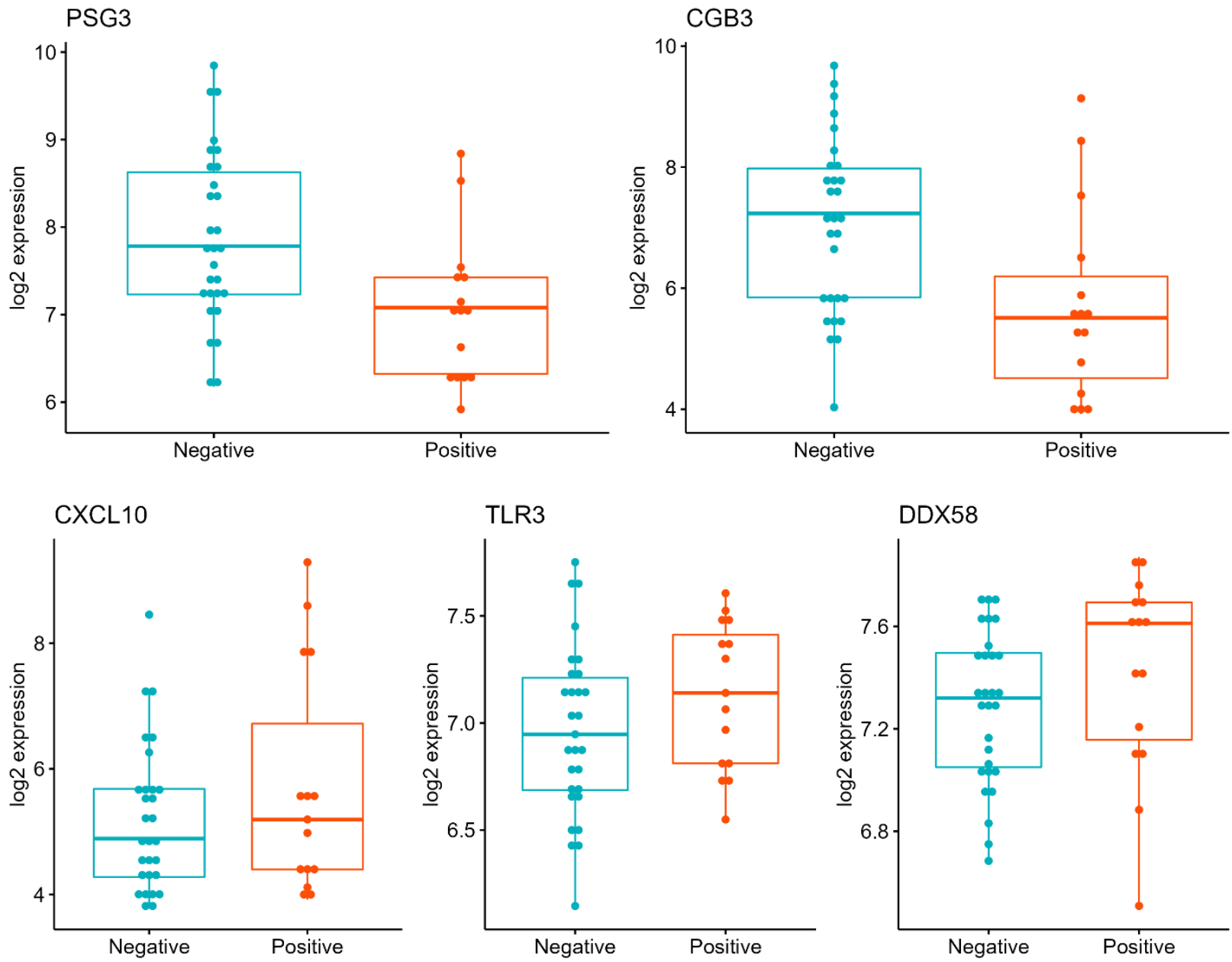